\title{
Emission tests of the AI-14RA aircraft engine under real operating conditions of PZL-104 'Wilga' plane
}

\author{
Due to a rapid development of air transportation there is a need for the assessment of real environmental risk related \\ to the aircraft operation. The main environmental perils are the toxic exhaust emissions. The paper presents the results \\ of the emission tests of a small airplane engine under real operating conditions.
}

Key words: emission, small aircraft engine, measurements under real operating conditions

\section{Pomiary emisji spalin z lotniczego silnika AI-14RA w rzeczywistych warunkach eksploatacji samolotu PZL-104 Wilga}

\begin{abstract}
Z uwagi na gwałtowny rozwój komunikacji lotniczej istnieje potrzeba oceny realnej emisji związów szkodliwych zwiazanej z eksploatacja statków powietrznych. Głównymi zagrożeniami dla środowiska naturalnego sa produkty niecatkowitego i niezupetnego spalania zawarte $w$ spalinach. W artykule przedstawiono rezultaty badań emisji spalin silnika matego samolotu w rzeczywistych warunkach lotu.

Słowa kluczowe: emisja, silnik małego samolotu, pomiary w rzeczywistych warunkach lotu
\end{abstract}

\section{Introduction}

One of the factors stimulating the technology advancement in all the branches of industry is the necessity to restrict its negative impact on the natural environment. The application of advanced technologies and their further development forces a constant verification of the operating conditions of machines and their impact on the living organisms. Transport is one of the most dynamically advancing branch of economy and its changes are strictly related to the world's economic development. The development of means of transportation is aimed at a reduction of the toxic emissions during operation of all kinds of motor vehicles.

The emission of carbon monoxide and particulate matter is still a serious threat- constituting an obstacle in the development of combustion engines. The applicable regulations related to the influence of the air transportation on the environment introduced by EPA (Environmental Protection Agency), ICAO (International Civil Aviation Organization) contained in JAR 34 (Joint Aviation Requirements), FAR 34 (Fuel Venting and Exhaust Emission Requirements for Turbine Engine Powered Airplanes), mostly pertain to the emission of noise and toxic compounds, $\mathrm{NO}_{\mathrm{x}}$ in particular. They refer to jet engines and have stationary test procedures depending on the engine operating conditions. The said standards do not include aviation piston engines.

Due to the differences in the combustion processes between piston and jet engines it should be assumed that the toxic emissions of a piston combustion engine will be higher than those of a jet engine. A considerable growth in the number of general aviation class aircraft may contribute to an increase in the emissions from piston aviation engines, which may pose a threat to the natural environment. The emission of $\mathrm{NO}_{\mathrm{x}}$ in the upper parts of the atmosphere is particularly disadvantageous as it fosters the greenhouse effect.

\section{Wprowadzenie}

Rozwój techniki i technologii we wszystkich dziedzinach przemysłu powoduje konieczność ograniczania jego negatywnego wpływu na środowisko naturalne. Stosowanie zaawansowanych technologii i ich ciągły rozwój zmuszają do ustawicznej weryfikacji istniejących warunków pracy maszyn i urządzeń oraz ich oddziaływania również na organizmy żywe.

Transport jest zaliczany do bardzo dynamicznie rozwijającej się dziedziny gospodarki, a jego zmiany pozostają w bezpośredniej relacji z rozwojem gospodarczym świata. Rozwój środków transportu jest ukierunkowany przede wszystkim na ograniczanie emisji szkodliwych składników spalin emitowanych podczas eksploatacji wszelkiego rodzaju pojazdów silnikowych.

Nadal poważnym zagrożeniem jest emisja dwutlenku węgla oraz cząstek stałych - stanowiące barierę rozwoju współczesnych silników spalinowych. Obecne przepisy dotyczące wpływu środków transportu lotniczego na środowisko wprowadzone przez EPA (Environmental Protection Agency - Agencja Ochrony Środowiska), ICAO (International Civil Aviation Organization - Organizacja Międzynarodowego Lotnictwa Cywilnego), zawarte w JAR 34 (Joint Aviation Requirements - przepisy określające normy emisji spalin), FAR 34 (Fuel Venting and Exhaust Emission Requirements for Turbine Engine Powered Airplanes - przepisy określające normy emisji spalin), dotyczą głównie emisji hałasu i związków szkodliwych spalin ze szczególnym uwzględnieniem tlenków azotu. Dotyczą one silników przepływowych i zawierają procedury testów stacjonarnych, w zależności od warunków pracy silnika. Przywołane normy nie dotyczą lotniczych silników tłokowych.

Ze względu na odmienność procesu spalania realizowanego w silniku tłokowym od procesu spalania w silniku turbinowym należy spodziewać się, że emisja związków szkodliwych spa- 
The current level of technology advancement related to the measurement of the toxic emissions enables testing means of transportation under real operating conditions [1-7]. Such investigations allow the determining of the emissions of individual toxic compounds under real traffic conditions. They also allow an assessment of the operating specificity of a means of transportation in terms of time density of engine loads. Such information allows a determining of the operating states of the powertrain along with their share in the total engine operating time. Such information may then be juxtaposed to the stationary testing procedures which, in the future, may facilitate the optimization of the operating points of engines operated in transportation.

The possibilities of using portable measurement systems are of particular importance in the investigations of small aircraft under real operating conditions. The gross payload of the plane and the cargo space is decisive here - the minimization of the testing equipment is an advantage in the case of portable systems.

\section{The object of the research}

The investigations of the exhaust emissions of a small plane were carried out on PZL-104 Wilga (Fig. 1) fitted with an engine AI-14RA (Fig. 2).

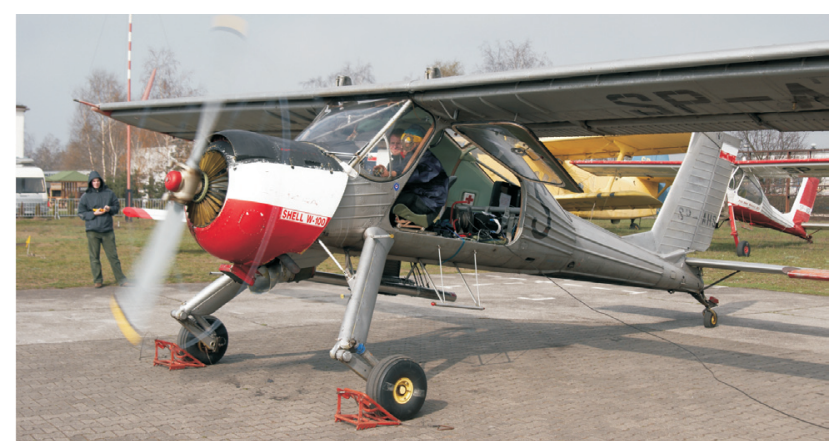

Fig. 1. PZL-104 Wilga

Rys. 1. PZL-104 Wilga

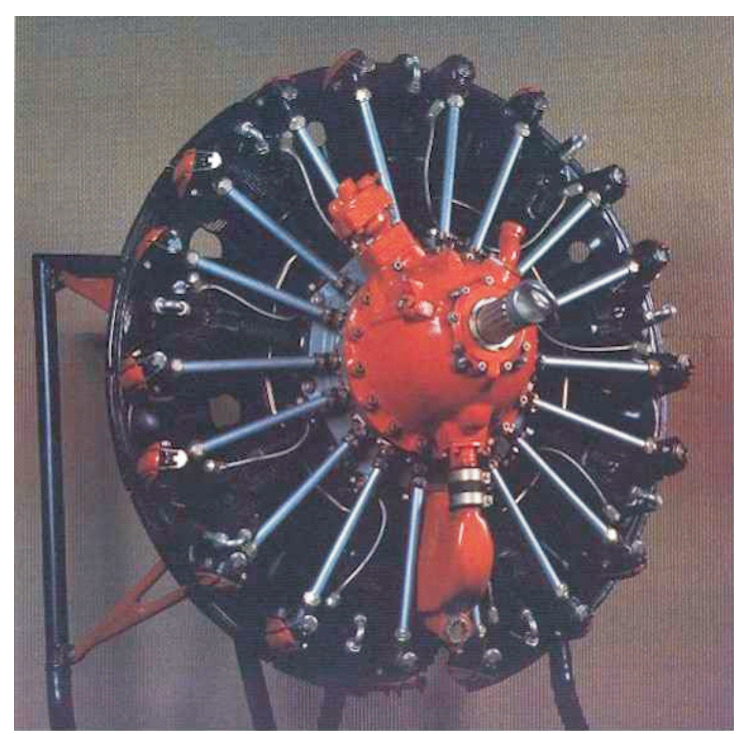

Fig. 2. Engine AI-14RA [10]

Rys. 2. Silnik AI-14RA [10] lin silnika tłokowego będzie większa niż silnika turbinowego. Znaczny wzrost liczby użytkowanych samolotów klasy general aviation może przyczynić się do zwiększenia emisji spalin z tłokowych silników lotniczych, co może stanowić zagrożenie dla środowiska naturalnego. Szczególnej uwagi wymaga emisja tlenków azotu w wyższych partiach atmosfery, która skutkuje zwiększeniem efektu cieplarnianego.

Obecny poziom techniki pomiarowej związanej z badaniem emisji związków szkodliwych spalin umożliwia realizację badań środków transportu w rzeczywistych warunkach eksploatacji [1-7]. Badania tego typu pozwalają określić poziom wartości emisji poszczególnych związków szkodliwych spalin w rzeczywistych warunkach ruchu. Ponadto umożliwiają ocenę specyfiki eksploatacyjnej środka transportu pod względem czasowego obciążenia silnika. Informacje te pozwalają na wyznaczenie stanów eksploatacyjnych zespołu napędowego wraz z ich udziałem w całkowitym czasie eksploatacji. Mogą być również odniesione do procedur testów stacjonarnych, co w przyszłości może umożliwić optymalizację punktów pracy silników eksploatowanych w różnych środkach transportu.

Możliwości wykorzystania mobilnej aparatury badawczej nabierają szczególnego znaczenia w badaniach małych samolotów w warunkach rzeczywistej eksploatacji. Decydujące znaczenie ma tu dopuszczalna masa ładunku, jaki samolot może unieść oraz przestrzeń ładunkowa; wtedy minimalizacja urządzeń pomiarowych jest istotną zaletą.

\section{Obiekt badawczy}

Badania emisji związków szkodliwych zawartych w spalinach silnikowych małego samolotu wykonano z wykorzystaniem samolotu PZL-104 Wilga (rys. 1) z silnikiem AI-14RA (rys. 2).

Ze względu na powtarzalność badań istotną rolę odgrywają przede wszystkim predyspozycje i styl lotu pilota, a także parametry samolotu. Parametry samolotu PZL-104 Wilga zestawiono w tab. 1.

Table 1. Technical data PZL-104 Wilga [11]

Tabela 1. Dane techniczne PZL-104 Wilga [11]

\begin{tabular}{|l|c|}
\hline Version/wersja & PZL-104 Wilga 35 \\
\hline Wing span/rozpiętość & $11,12 \mathrm{~m}$ \\
\hline Length/dtugość & $8,10 \mathrm{~m}$ \\
\hline Height/wysokość & $2,94 \mathrm{~m}$ \\
\hline Wing area/powierzchnia nośna & $15,50 \mathrm{~m} 2$ \\
\hline Kerb weight/masa własna & $900 \mathrm{~kg}$ \\
\hline Payload/masa użyteczna & $400 \mathrm{~kg}$ \\
\hline Gross weight/masa całkowita & $1300 \mathrm{~kg}$ \\
\hline Engine/silnik & $195 \mathrm{dm} 3$ \\
\hline Fuel capacity/zapas paliwa & $200 \mathrm{~km} / \mathrm{h}$ \\
\hline Maximum speed/prędkość maksymalna & $157 \mathrm{~km} / \mathrm{h}$ \\
\hline Cruising speed/prędkość przelotowa & $68 \mathrm{~km} / \mathrm{h}$ \\
\hline Minimum speed/prędkość minimalna & $5 \mathrm{~m} / \mathrm{s}$ \\
\hline Climb speed/prędkość wznoszenia & $4000 \mathrm{~m}$ \\
\hline Maximum altitude/pułap & $680 \mathrm{~m}$ \\
\hline Range/zasięg & \\
\hline
\end{tabular}


Due to the repeatability of the test results important are the pilot's predispositions and piloting style as well as the parameters of the plane. The plane parameters (PZL-104 Wilga) have been shown in table 1 .

The design of an aviation engine, its technology level and workmanship and, most importantly, its condition play a very important role in the aircraft emission tests. The tested plane PZL-104 Wilga was fitted with a $10.16 \mathrm{dm}^{3} 9$ cylinder star spark ignition air cooled piston engine AI-14RA. The engine was fitted with a single speed mechanically driven radial blower. The drive of the propeller W530-D11 was based on a planetary transmission of a gear ratio $0.787: 1$.

For the purpose of the emission tests the exhaust system of the plane was extended by $3 \mathrm{~m}$. This allowed the measurement of the emissions at a spot that ensured a proper fitting of the measuring sensor (Fig. 3). Such a long distance was needed to lower the temperature of the exhaust gases - because of a very short original exhaust system the exhaust gas temperature reaches approximately $1300 \mathrm{~K}$.

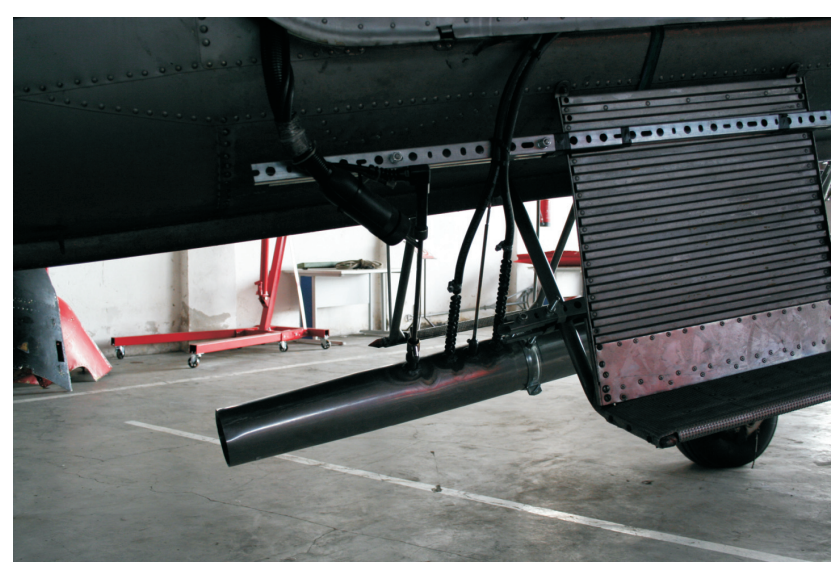

Fig. 3. Location of the measuring sensor

Rys. 3. Miejsce zamocowania sondy poboru spalin

\section{Measurement equipment}

The aim of the performed tests was the evaluation of the toxic emissions under real operating conditions of the aircraft. This task required the application of two measuring systems. The first- exhaust gas analyzer TESTO 360 (Fig. 4) - was used for the measurement of the toxic compound concentration in the exhaust (the analyzer measuring data have been shown in tab. 3). The other system-data acquisition system LogBook 360 along with the analog input module DBK 214 (Fig. 5) by IOtech was used to record the basic operating parameters of the engine i.e. pressure, ambient temperature, ambient humidity, exhaust gas temperature at its uptake point as well as the parameters related to the flow of the exhaust gases.

The measuring parameters of TESTO 360 enable recording of the measurements of the toxic compound concentration with the frequency of
Duże znaczenie podczas pomiarów emisji związków szkodliwych spalin ze statków powietrznych ma konstrukcja silnika, jego poziom technologiczny i standard wykonania, a przede wszystkim stan eksploatacyjny. Wykorzystany do badań samolot PZL-104 Wilga był napędzany silnikiem tłokowym o zapłonie iskrowym AI-14RA, 9-cylindrowym o układzie cylindrów jednorzędowej gwiazdy, o pojemności skokowej 10,16 $\mathrm{dm}^{3}$, chłodzony powietrzem. Silnik był wyposażony $\mathrm{w}$ dmuchawę promieniową, jednobiegową napędzaną mechanicznie. Napęd śmigła W530-D11 był realizowany przez przekładnię planetarną o przełożeniu 0,787:1.

Na potrzeby pomiarów emisji związków szkodliwych spalin dokonano przedłużenia układu wylotowego o $3 \mathrm{~m}$. Dzięki temu pomiar emisji związków szkodliwych znajdował się w miejscu pozwalającym na poprawny montaż sondy pomiarowej (rys. 3). Tak znaczna odległość była uwarunkowana również obniżeniem temperatury spalin - ze względu na bardzo krótki układ wylotowy osiąga ona bezpośrednio za silnikiem wartość około $1300 \mathrm{~K}$.

\section{Aparatura pomiarowa}

Celem przeprowadzonych badań była ocena emisji związków szkodliwych spalin podczas rzeczywistych warunków eksploatacyjnych samolotu. Zadanie to wymagało zastosowania dwóch systemów pomiarowych. Pierwszy - analizator spalin TESTO 360 (rys. 4) - wykorzystano do pomiaru stężenia związków szkodliwych w spalinach silnikowych (możliwości pomiarowe analizatora przedstawiono w tab. 2). Drugi - system akwizycji danych LogBook 360 wraz z modułem wejść analogowych DBK 214 (rys. 5) firmy IOtech - użyto do rejestracji podstawowych parametrów eksploatacyjnych silnika, m.in. ciśnienia i temperatury otoczenia, wilgotności powietrza, temperatury spalin w punkcie ich poboru oraz parametrów związanych z przepływem spalin.

Analizator TESTO 360 pozwala na rejestrację wyników pomiarów stężeń związków szkodliwych zawartych w spalinach z częstotliwością $0,25 \mathrm{~Hz}$. Z tego względu pomiary pozostałych parametrów - z wykorzystaniem systemu akwizycji danych LogBook 360 - rejestrowano z taką samą częstotliwością. Dodatkowo system akwizycji wyposażono w odbiornik GPS 18x firmy Garmin (rys. 6), co umożliwiło rejestrację parametrów położenia samolotu w przestrzeni

Table 2. TESTO 360 measuring parameters

Tabela 2. Możliwości pomiarowe analizatora TESTO 360

\begin{tabular}{|l|c|c|}
\hline $\begin{array}{l}\text { Measured quantity/ } \\
\text { wielkość mierzona }\end{array}$ & $\begin{array}{c}\text { Measurement ran- } \\
\text { ge/zakres pomiaru }\end{array}$ & Measurement error/bład pomiaru \\
\hline $\mathrm{CO}$ & $0-10000 \mathrm{ppm}$ & below $2.0 \%$ of the range/poniżej 2\% zakresu \\
\hline $\mathrm{CO} 2$ & $0-25 \% \mathrm{obj}$. & below $1.5 \%$ of the range/poniżej 1,5\% zakresu \\
\hline $\mathrm{HC}$ & $0-2.5 \% \mathrm{obj}$. & below $10 \%$ of the range/poniżej $10 \%$ zakresu \\
\hline $\mathrm{NOx}$ & $0-3500 \mathrm{ppm}$ & below $3.8 \%$ of the range/poniżej 3,8\% zakresu \\
\hline $\mathrm{SO} 2$ & $0-5000 \mathrm{ppm}$ & below $2.5 \%$ of the range/poniżej $2,5 \%$ zakresu \\
\hline $\mathrm{O} 2$ & $0-21 \% \mathrm{obj}$. & below $1.2 \%$ of the range/poniżej $1,2 \%$ zakresu \\
\hline $\begin{array}{l}\text { Exhaust gas tempe- } \\
\text { rature/temp. spalin }\end{array}$ & $20-800^{\circ} \mathrm{C}$ & \\
\hline
\end{tabular}


$0.25 \mathrm{~Hz}$. Hence, the measurements of the other parameterswith the use of the data acquisition system LogBook 360

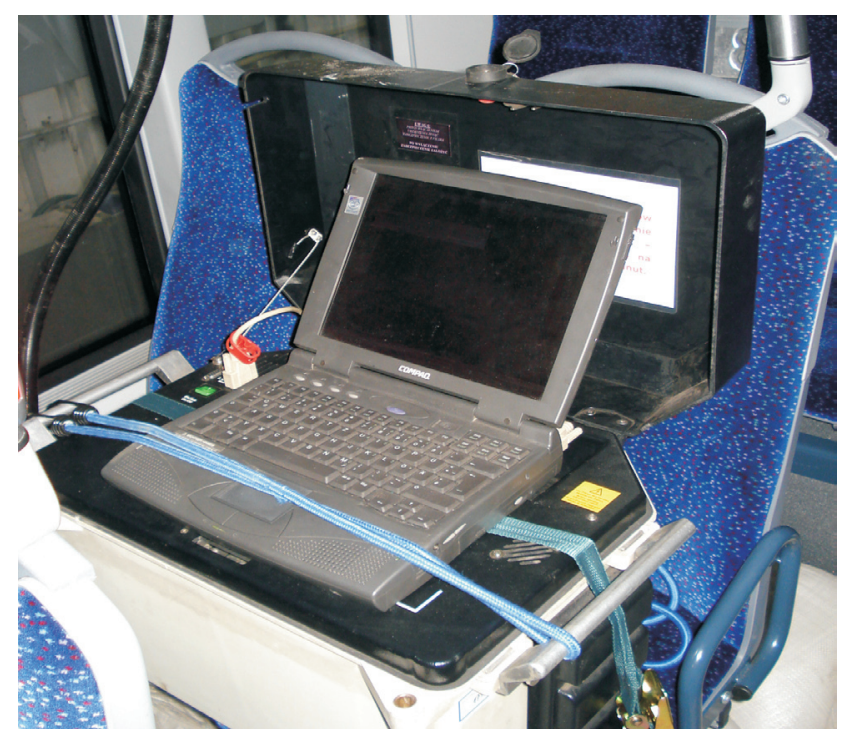

Fig. 4. Exhaust gas analyzer TESTO 360 Rys. 4. Analizator spalin TESTO 360

- were recorded with the same frequency. Additionally, the data acquisition system was fitted with a GPS transceiver $18 \mathrm{x}$ by Garmin (Fig. 6), which enabled the recording of the plane position parameters in a 3-dimensional space. Based on the recorded position parameters the plane trajectory was determined.

\section{Test results}

The measurement of the toxic emissions from the AI-14RA engine fitted in the aircraft PZL-104 Wilga was carried out from taxi until landing. In a standard type of flight we can distinguish several phases. These are: taxi, takeoff, climb, steady flight, approach to landing, landing taxi to apron. Depending on the performed task the time share of the individual phases in the whole flight differs. Most frequently the taxi and takeoff as well as approach to landing do not have a large share in the whole flight. Nevertheless the scope of the investigations comprised all these mentioned phases.

The route was set from the Airstrip of Aeroklub Poznański (Poznań Aeroclub) in Ligowiec near Kobylnica and the town of Wagrowiec of a distance of $45 \mathrm{~km}$ from the airstrip. Thus, the total flight distance amounted to approximately $90 \mathrm{~km}$. The actual trajectory was determined based on the recorded parameters of the GPS transceiver (Fig. 7).

During the flight the concentrations of the toxic compounds in the exhaust were recorded with the use of the TESTO 360 analyzer. Due to the exceeded maximum values of the measuring range of the analyzer the measurement of the hydrocarbon and $\mathrm{CO}$ was not possible. Hence, only the concentrations of the $\mathrm{NO}_{x}$ and $\mathrm{SO}_{2}$ were measured, which enabled determining their correlation with the cruising altitude, engine speed and exhaust temperature at its uptake (Fig. 8). The shown courses enable a detailed determining of the individual phases of the flight. trójwymiarowej. Na podstawie zarejestrowanych parametrów położenia określano trajektorię lotu samolotu.

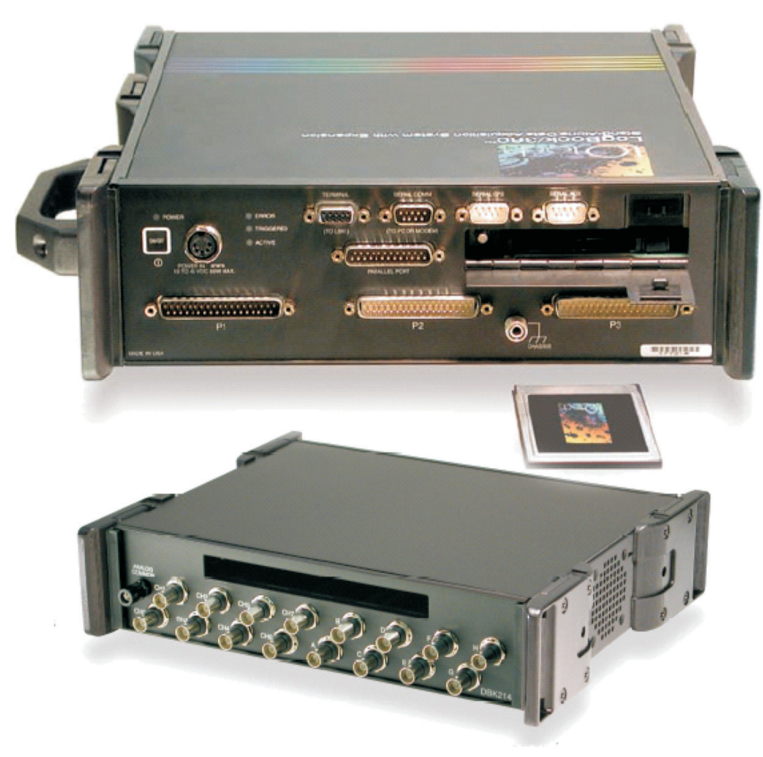

Fig. 5. Data Acquisition system LogBook 360 together with the analog input module DBK 214 [9]

Rys. 5. System akwizycji danych LogBook 360 wraz z modułem wejść analogowych DBK 214 [9]

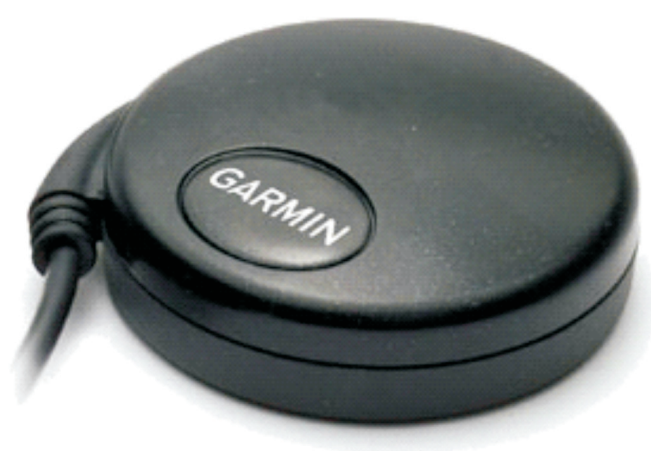

Fig. 6. GPS transceiver $18 x$ by Garmin [8] Rys. 6. Odbiornik GPS 18x firmy Garmin [8]

\section{Wyniki badań}

Pomiaru emisji związków szkodliwych zawartych w spalinach silnika AI-14RA podczas lotu samolotem PZL-104 Wilga dokonano od rozpoczęcia kołowania na miejsce startu samolotu do wylądowania. W standardowym przebiegu lotu można wyszczególnić kilka faz: kołowanie na start, start, wznoszenie, ustalona faza lotu, podejście do lądowania, lądowanie oraz kołowanie na miejsce postoju. W zależności od wykonywanego zadania różny jest udział czasowy poszczególnych fazy w całkowitym przebiegu lotu. Najczęściej faza kołowania i startu oraz podejścia do lądowania i lądowania wraz z kołowaniem na miejsce postoju nie stanowią dużego udziału w całkowitym czasie lotu. Niemniej jednak zakres badań obejmował wszystkie wymienione wcześniej fazy. 


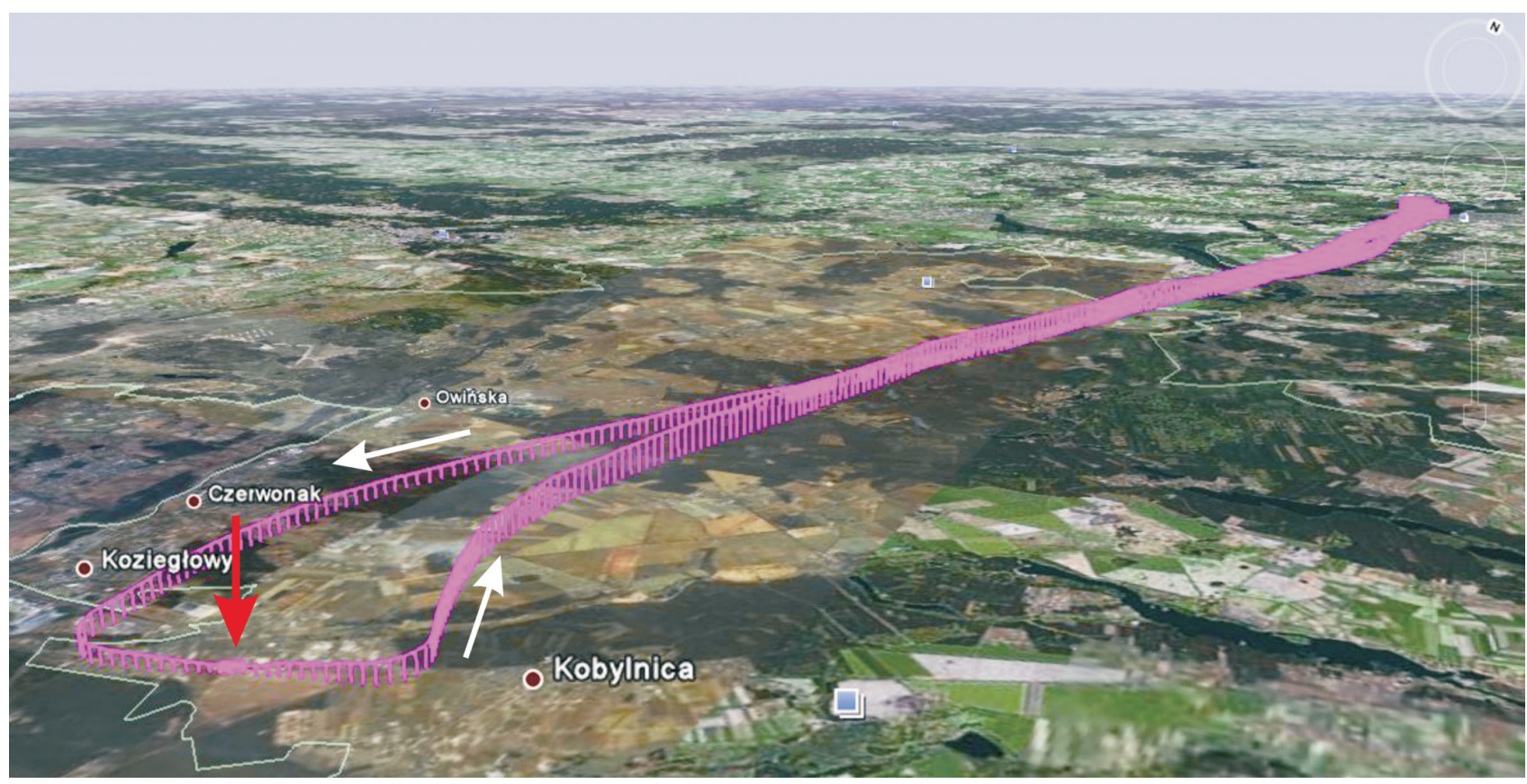

Fig. 7. Flight trajectory during the testing (red arrow takeoff spot, white arrow- flight direction)

Rys. 7. Trajektoria lotu podczas badań (strzałka czerwona-miejsce startu, strzałka biała - kierunek lotu)

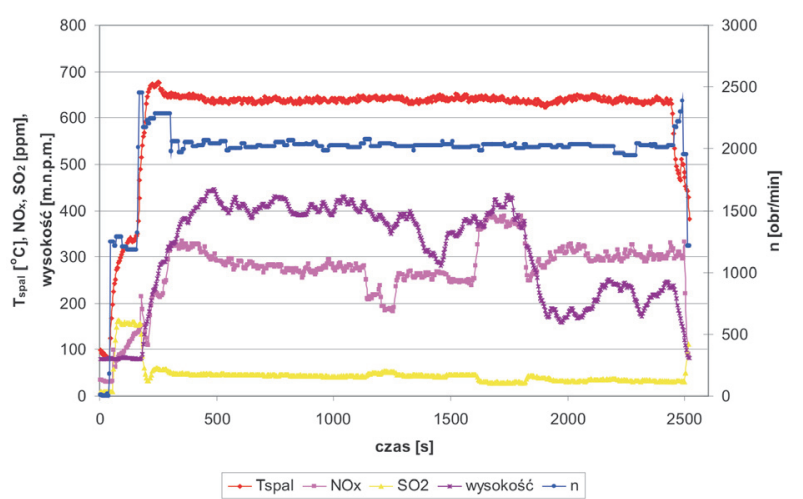

Fig. 8. The course of the values of selected flight parameters

Rys. 8. Przebiegi wartości wybranych parametrów w czasie lotu

The visualization of the distribution of the $\mathrm{NO}_{\mathrm{x}}$ and $\mathrm{SO}_{2}$ concentration in the takeoff and landing phases have been shown in Figs. 9 and 10. The obtained results indicate a tight correlation of the engine speed with the changes in the exhaust temperature values and the $\mathrm{NO}_{\mathrm{x}}$ concentration. This dependency is related to a fixed setting of the rotor blade generating the effect of the engine load. While analyzing the changes in the instantaneous $\mathrm{SO}_{2}$ emission we need to take into account that it is a consequence of combustion of aviation fuel that contain sulfur compounds. We can thus assume that the values of instantaneous concentration of $\mathrm{SO}_{2}$ well reflect the instantaneous fuel consumption, which depends on the engine load and air fuel mixture composition.
Trasę lotu ustalono na odcinku między lotniskiem Aeroklubu Poznańskiego w miejscowości Ligowiec koło Kobylnicy, a miejscowością Wągrowiec, oddaloną o około $45 \mathrm{~km}$ od punktu startowego. W związku z tym łączny dystans lotu wynosił około $90 \mathrm{~km}$. Rzeczywistą trajektorię lotu wyznaczono na podstawie rejestrowanych parametrów odbiornika GPS podczas lotu (rys. 7).

Podczas lotu rejestrowano wartości stężeń związków szkodliwych zawartych w spalinach silnikowych z wykorzystaniem analizatora TESTO 360. Z powodu przekroczonych wartości maksymalnych zakresu pomiarowego analizatora nie była możliwa ocena wartości stężenia węglowodorów oraz tlenku węgla. W związku z tym wykonano pomiary stężenia tlenków azotu oraz dwutlenku siarki, co pozwoliło na opracowanie ich wzajemnych korelacji z wysokością lotu i prędkością obrotową silnika oraz temperaturą spalin w miejscu ich poboru (rys. 8). Uwidocznione przebiegi pozwalają na dokładne określenie poszczególnych faz lotu samolotu.

Wizualizację rozkładu stężenia tlenków azotu i dwutlenku siarki w fazach startu i lądowania oraz nawrotu przedstawiono na rys. 9 i 10. Uzyskane wyniki wykazują ścisłą korelację prędkości obrotowej silnika ze zmianami wartości temperatury spalin oraz stężeniem tlenków azotu. Zależność ta jest uwarunkowana stałym ustawieniem skoku śmigła, którego efektem jest obciążenie silnika. Analizując zmiany wartości chwilowej emisji dwutlenku siarki, należy wziąć pod uwagę to, że jest on konsekwencją spalania paliwa lotniczego, które zawiera związki siarki. Można zatem wnioskować, iż wartości chwilowego stężenia dwutlenku siarki dobrze odzwierciedlają chwilowe zużycie paliwa, co w efekcie jest zależne od obciążenia silnika i składu mieszanki paliwowo-powietrznej. 

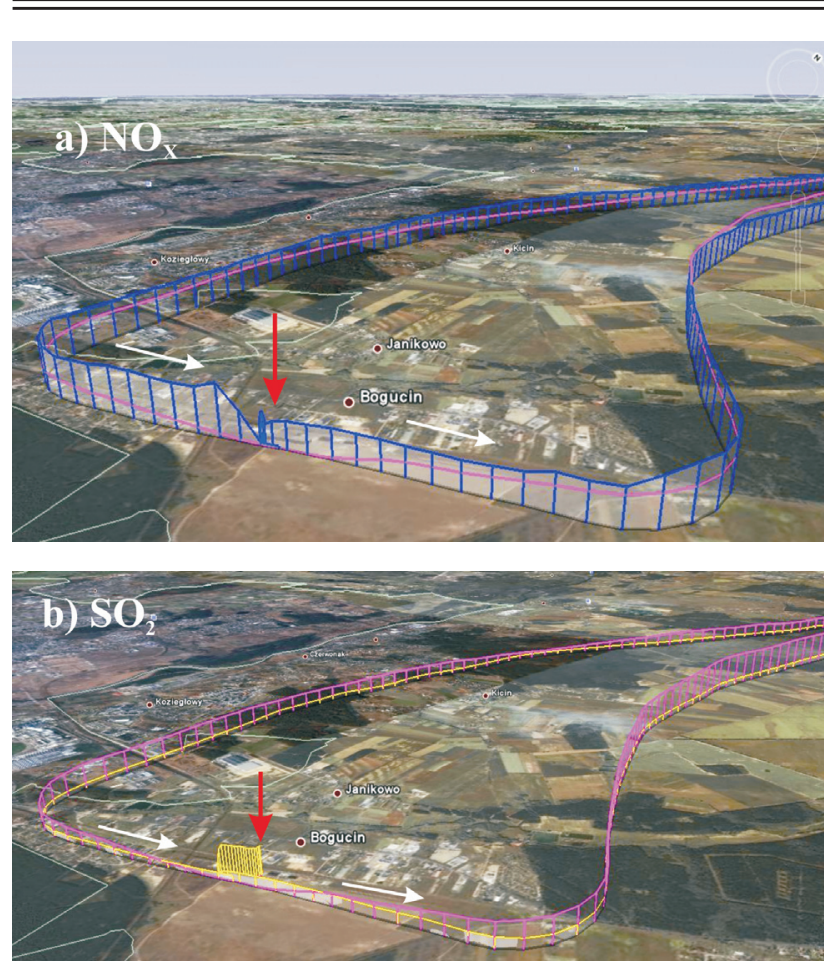

Fig. 9. Instantaneous values of concentrations of selected compounds against the plane trajectory (takeoff and landing); a) $\mathrm{NO}_{x}$ concentration, b) $\mathrm{SO}_{2}$ concentration, (red arrow takeoff spot, white arrow-flight direction)

Rys. 9. Chwilowe wartości stężenia wybranych zwiazków na tle trasy lotu (start i lądowanie); a) stężenie tlenków azotu, b) stężenie dwutlenku siarki, (strzałka czerwona-miejsce startu, strzałka biała-kierunek lotu)

In Figure 9 we can distinguish the takeoff, climb and landing phases; in these phases the highest engine load occurs. Also in these same phases the engine is fuelled with a rich air fuel mixture in order to boost the certainty of proper mixture firing. Rich mixture, due to a low excess air coefficient, contributes to the lowering of the maximum combustion temperature. This results in a relatively low value of $\mathrm{NO}_{x}$ (approximately 200 ppm) and a significantly high concentration of $\mathrm{SO}_{2}$ (approximately $170 \mathrm{ppm}$ ). The recorded exhaust gas temperature was approximately $600 \mathrm{~K}$.

In the steady phase of the flight the value of the exhaust gas temperature amounts to approximately $900 \mathrm{~K}$ and the concentrations of the individual toxic compounds stabilize and are approx. $300 \mathrm{ppm}$ for $\mathrm{NO}_{\mathrm{x}}$ and $50 \mathrm{ppm}$ for $\mathrm{SO}_{2}$. The steady character of the concentrations of the toxic compounds does not change during the return phase (Fig. 10). In all the flight phases the values of the hydrocarbons and $\mathrm{CO}$ concentration exceeded the maximum measuring capacity of the analyzer. These values according to the manufacturer specifications are: for $\mathrm{HC}-2.5 \%$ vol., for $\mathrm{CO}-10000 \mathrm{ppm}$. It needs to be stated that the emission of these compounds is not determined but is higher than the maximum range of the analyzer.

\section{Conclusions}

The performed tests and the analysis of the obtained results confirm how significantly impactful many flight
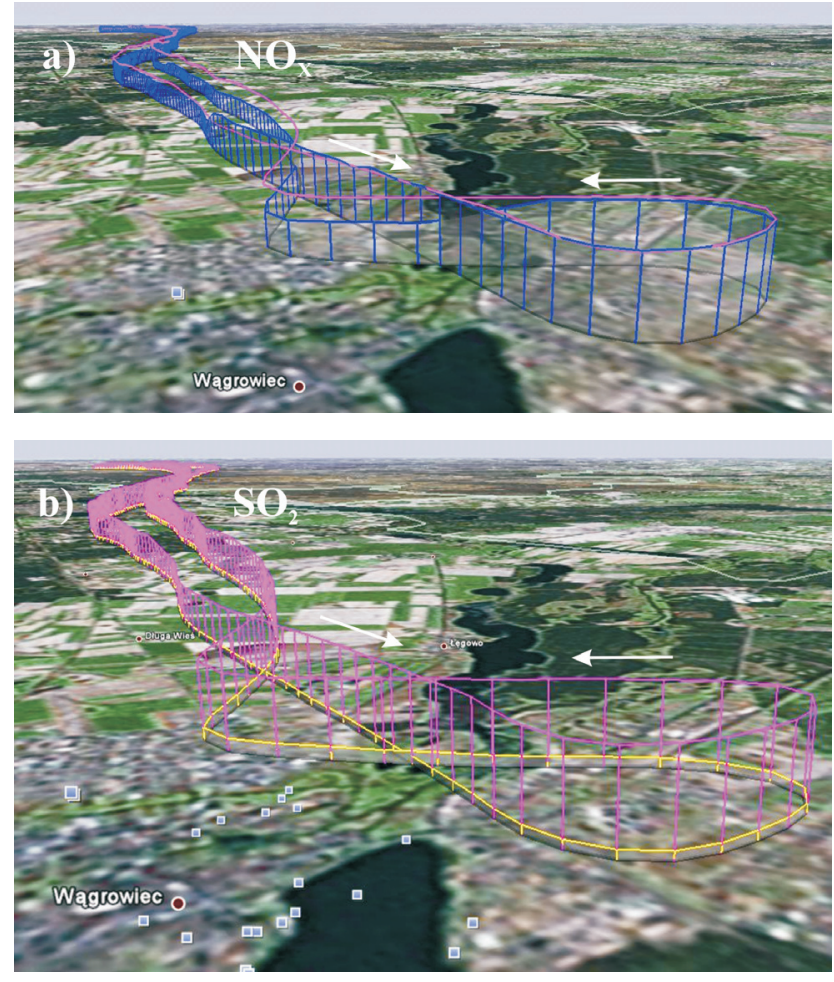

Fig. 10. Instantaneous values of concentrations of selected compounds against the plane trajectory (return); a) $\mathrm{NO}_{\mathrm{x}}$ concentration, b) $\mathrm{SO}_{2}$ concentration, (red arrow takeoff spot, white arrow- flight direction)

Rys. 10. Chwilowe wartości stężenia wybranych związów na tle trasy lotu (nawrót); a) stężenie tlenków azotu, b) stężenie dwutlenku siarki, (strzałka biała-kierunek lotu)

Na rysunku 9 można wyodrębnić fazę startu i wznoszenia oraz lądowania; w tych fazach występuje największe obciążenie silnika. Również w tych fazach silnik samolotu jest zasilany bogatą mieszanką paliwowo-powietrzną w celu zwiększenia pewności występowania jej zapłonów. Bogata mieszanka z racji małego współczynnika nadmiaru powietrza przyczynia się również do obniżenia maksymalnej temperatury spalania. Skutkuje to stosunkowo małą wartością stężenia tlenków azotu (około 200 ppm), a zarazem znacząco wysoką wartością stężenia dwutlenku siarki (około 170 ppm). Zarejestrowana wartość temperatury spalin to około $600 \mathrm{~K}$.

W ustalonej fazie lotu wartość temperatury spalin wynosi około $900 \mathrm{~K}$, a stężenie poszczególnych związków szkodliwych stabilizuje się i wynosi dla tlenków azotu około 300 ppm, a dla dwutlenku siarki około 50 ppm. Ustalony charakter stężenia związków szkodliwych nie ulega zmianie również podczas fazy nawrotu (rys. 10). We wszystkich fazach lotu wartości stężenia węglowodorów oraz tlenku węgla przekraczały wartości zakresów pomiarowych analizatora. Wartości te zgodnie z dokumentacją techniczną analizatora wynoszą: dla $\mathrm{HC}-2,5 \%$ obj., dla CO - 10000 ppm. Pomijając te wartości należy stwierdzić, że emisja tych związków nie jest określona, ale jest większa od wartości granicznego zakresu pomiarowego analizatora.

\section{Podsumowanie}

Przeprowadzone badania i analiza uzyskanych wyników potwierdzają znaczący wpływ wielu parametrów związanych 
specific parameters are. The paper confirms a considerable dependency of the toxic compound concentration on the aircraft operating conditions which, to a large extent, are related to the pilots predispositions and experience. The tests have confirmed the significance of the dynamics of the individual flight phases (climb phase in particular) on the concentration of the toxic compounds.

The performed tests are to be treated as introductory and preliminary. The analysis of the obtained results pointed to a significant problem of an elevated concentration of $\mathrm{CO}$ and $\mathrm{HC}$ in the whole range of the engine operation. These results should be correlated with the results for the same aircraft fitted with a modern engine.

The obtained information may be used to verify and develop research procedures of small aircraft that do not have a sufficient payload to be fitted with a specialized full sized testing devices. Finally, this type of tests may contribute to the development of universal testing procedures that determine the emissivity of small aircraft and their impact on the environment.

Paper reviewed z indywidualną specyfiką realizowanego lotu. W artykule wykazano dużą zależność stężenia związków szkodliwych od warunków eksploatacyjnych samolotu, które znacznie zależą od predyspozycji pilota i jego umiejętności. Przeprowadzone badania potwierdziły istotny wpływ na stężenie związków szkodliwych dynamiki poszczególnych faz lotu, a w szczególności fazy wznoszenia samolotu.

Przeprowadzone badania należy traktować jako wstępne, o charakterze poznawczym. Analiza uzyskanych wyników wskazała na istotny problem zwiększonego stężenia tlenku węgla oraz węglowodorów w całym zakresie pracy silnika. Wyniki te należałoby skorelować z wynikami uzyskanymi dla samolotu tego samego typu, ale napędzanego silnikiem nowszej generacji.

Uzyskane informacje mogą być wykorzystane do weryfikacji i opracowania procedur badawczych dla małych samolotów, które nie mają dostatecznej ładowności do zamontowania specjalistycznej pełnowymiarowej aparatury badawczej. Ostatecznie realizacja tego typu badań może przyczynić się do ustalenia uniwersalnych procedur badawczych określających emisyjność małych samolotów i ich oddziaływanie na środowisko.

\section{Nomenclature/Skróty i oznaczenia}

EPA Environmental Protection Agency/Agencja Ochrony Środowiska

ICAO International Civil Aviation Organization/Organizacja Międzynarodowego Lotnictwa Cywilnego

JAR 34Joint Aviation Requirements/przepisy określajace normy emisji spalin

FAR Fuel Venting and Exhaust Emission Requirements for Turbine Engine Powered Airplanes/przepisy określajace normy emisji spalin

$\mathrm{CO}$ Carbon monoxide/tlenek węgla

$\mathrm{HC}$ Hydrocarbons/węglowodory

$\mathrm{SO}_{2} \quad$ Sulfur dioxide/dwutlenek siarki

$\mathrm{NO}_{x} \quad$ Nitrogen oxide/tlenki azotu

\section{Bibliography/Literatura}

[1] Gao Y., Checkel M.D.: Emission Factors Analysis for Multiple Vehicles Using an On-Board, In-Use Emissions Measurement System. SAE Paper 2007-01-1327.

[2] Khair M., Khalek I., Guy J.: Portable Emissions Measurement for Retrofit Applications - The Beijing Bus Retrofit Experience, SAE Technical Paper Series 2008-01-1825.

[3] Korniski T., Gierczak C., Wallington T.: Laboratory Evaluation of the 2.5 Inch Diameter SEMTECH ${ }^{\circledR}$ Exhaust Flow Meter with Gasoline Fueled Vehicles. Sensors 4th Annual SUN (SEMTECH User Network) Conference, 2007.

Prof. Jerzy Merkisz, DSc. DEng. - Professor in the Faculty of Machines and Transportation at Poznań University of Technology.

Prof. dr hab. inż. Jerzy Merkisz - profesor na Wydziale Maszyn Roboczych i Transportu Politechniki Poznańskiej.

e-mail: jerzy.merkisz@put.poznan.pl

[4] Merkisz J., Pielecha J., Gis. W.: Gasoline and LPG Vehicle Emission Factors in a Road Test. SAE Technical Paper Series 2009-01-0937.

[5] Processing CITA Conference „Global Perspective on Roadworthiness Enforcement”, organized by International Motor Vehicle Inspection Committee. Chicago 24-28.05.2005.

[6] Quan H.: ARB's Stockton Heavy-Duty Vehicle Laboratory and Portable Emission Monitoring System (PEMS) Activities, Sensors 5th Annual SUN (SEMTECH User Network) Conference, 25-26.09.2008.

[7] Tsinoglou D., Koltsakis G., Samaras Z.: Performance of OBD Systems for Euro 4 Level Vehicles and Implications for the Future OBD Legislation. [In:] Predelli O.: Onboard-Diagnose II, Expert Verlag, 2007.

[8] www.garmin.com.pl

[9] www.iotech.com

[10] www.wsk1.kalisz.pl/index_p.htm

[11] pl.wikipedia.org/wiki/PZL-104_Wilga

Mr. Jacek Pielecha, DEng. - Doctor in the Faculty of Machines and Transportation at Poznań University of Technology.

Dr inż. Jacek Pielecha - adiunkt na Wydziale Maszyn Roboczych i Transportu Politechniki Poznańskiej. e-mail: jacek.pielecha@put.poznan.pl

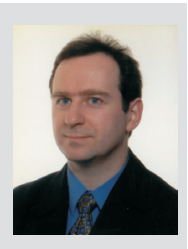

Mr. Jarosław Markowski, DEng. - Doctor in the Faculty of Machines and Transportation at Poznan University of Technology.

Dr inż. Jarosław Markowski - adiunkt na Wydziale Maszyn Roboczych i Transportu Politechniki Poznańskiej.

e-mail: jaroslaw.markowski@put.poznan.pl 